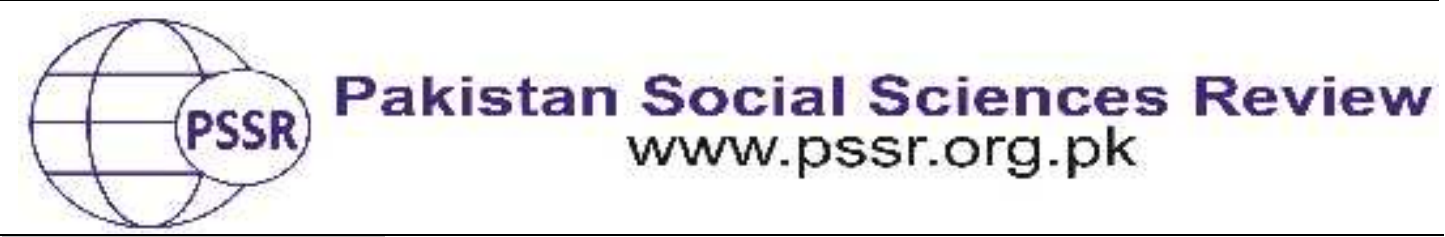

RESEARCH PAPER

\title{
Perception of Secondary School Teachers Regarding Emergency Education in Pakistan
}

Saqib Tanveer ${ }^{1}$ Dr. Ahmad Farooq Mashhadi ${ }^{2}$

1. Ph. D Scholar, Department of Education, Bahauddin Zakariya University, Multan, Punjab, Pakistan

2. Professor, Department of Education, Department of Education, Bahauddin Zakariya University, Multan, Punjab, Pakistan

\begin{tabular}{|c|c|}
\hline & \\
\hline & \multirow{16}{*}{$\begin{array}{l}\text { The conducted study aimed to find teachers 'perception } \\
\text { regarding education in emergencies in Pakistan. Affected areas } \\
\text { of AJK and KPK in the earthquake of } 2005 \text { were the population } \\
\text { of the study. Multistage sampling techniques were deployed to } \\
\text { select the emergency education programs, institutions and the } \\
\text { respondents. The respondents include teachers who taught in } \\
\text { emergency education programs. Data were obtained with the } \\
\text { help of questionnaires. The questionnaire was developed on the } \\
\text { bases of Inter Agency Network for Emergency Education. It } \\
\text { included community participation, teaching and learning, } \\
\text { Teachers and other educational Personnel, access and Learning } \\
\text { Environment and education Policy and coordination in } \\
\text { emergency education programs. Data obtained from the } \\
\text { respondents were tabulated and analysis in the SPSS version } 16 \\
\text { was carried out. The participation of community in EE } \\
\text { programs was inadequate. Modules about teaching methods, } \\
\text { teachers 'guides about teaching those books were not given to } \\
\text { teacher. There was insufficient staff to teach the affected } \\
\text { students. Education department did not supervise and monitor } \\
\text { the teaching staff properly. }\end{array}$} \\
\hline & \\
\hline & \\
\hline & \\
\hline & \\
\hline & \\
\hline & \\
\hline & \\
\hline & \\
\hline & \\
\hline & \\
\hline & \\
\hline & \\
\hline & \\
\hline & \\
\hline & \\
\hline
\end{tabular}

\section{Introduction}

In the present world Education in state of calamities such as war, conflicts and disasters is a matter of great concern for all educationists all over the world. A crisis situation is an emergency (Pigozzi, 1999). Geographic study of hazards has gained considerable prominence in the fifty years since Gilbert White's Human Adjustment to Floods dissertation was published. Over 130 hazards dissertations have been written in the U.S. and Canada (John, 1983). In such type of crises situation especial measures are possible to adopt which otherwise are impossible to carryout in normal situations. So we can say that an emergency is an opportunity to redesign or reshape education. Pigozzi's publications resulted in to a huge debate 
and the timely reaction to disaster in terms of education is the burning debate of educationists throughout world in educational institutions. Many research studies have been conducted by agencies working in the field of emergency education in different affected parts of the world either by disasters or conflicts. These parts include Afghanistan, East Timor, Mozambique, Somalia, Sudan and many other countries of the world. The observation that similar types of natural disasters produce different reactions based on a particular culture and location demands a thorough and detailed analysis, because the reasons are likely to be numerous and complex (Fausto, 2001).But it's a fact according to Buckland, 2005, is that the education is now becoming the integral part of response in post emergency situations throughout the world. Similarly Sincliar, 2002 declares important role of education in rebuilding the affected nation in crises or in disaster. A nation in any calamity needs education and schools to educate her youth. It is possible only through education to promote beliefs, ideas, values and the sense of citizenship to transform the nation as well as community but so for very little has been done in this connection (Sommers,2004).

The term emergency education was first used in 1990, when the printed material about the crises in different parts of the world like Somalia, Afghanistan and Sudan came before the world. This gave birth to the concept of complexity of emergencies in context of humanitarian bases.

According to (Foucault, 1977 \& Willis, 1981), the emergency situations forced the world for endeavor in emergency education and to understand diversify role of education that it can play in emergency situations. Early childhood care and development (ECCD) in emergencies is commonly defined as providing immediate, life-saving, comprehensive care for children (Kelse, 2019). No doubt schools are the adequate places for the moral, psychological and physical growth of the youth. Thus education is considered as priority in any extreme danger (Aguilar \& Retamal, 1998).

Natural disasters are the part of human life. They turn up in no time and leave shocking costs in seconds, including earthquakes, floods, hurricanes, tsunamis etc. During disaster whether natural or manly education plays a vital role in protecting and saving lives of people in emergencies (Anderson, 2005). A huge devastation confronted by Khyber Pakhtunkhaw and Azad Kashmir in 2005 due to earthquake. Education system of the two areas was severely affected. Round about eight thousand public schools were smashed in Kp and nearly two thousand in Azad Kashmir. Nearly 17000 students were martyred and twenty thousand had injuries (UNICEF, 2005).

In 2010 gigantic flood clearly revealed that Pakistan has yet to learn from her previous experiences. National Disaster and Risk Management (NDMA) Cell established for disasters remained unsuccessful to respond effectively the second time. 
In the present scenario it is seriously needed to have proper planning and preparedness in context of education in state of emergencies. Our country is facing frequent natural disasters due to its geographical position. During the last thirty years, around 10000 people died in disasters (Hamdani \& Shah, 2006).

According to Somers, 2004, governments, in natural disasters postpone the education because they are not able to plan it in such situations. While the Education For All and Millennium Development Goals of the 1990s and 2000s underpin the relation between education and social justice as a fundamental right (Novelli, Mieke, Cardozo, \& Smith, 2017).The motivation behind this study was to look in to the problems of EE in Pakistan. Education cherishes all kind of developments including emotional, physical, social and emotional prospects of children in disasters (Sinclair, 2002).

Generally the entire world and specifically in Pakistan academic investigations in EE are hardly conducted. In 2005, after earthquake the international donors and UNO founded intermediary schools and introduced "the school in a box" for first time in Pakistan". According to Bisin( 2007), the construction criteria of such schools were developed by UNICEF. Australian Agency for International Development (Aus. Aid) was major donor for education activities in the KP and AJK. Education is grave and schools are the only place which provide stability and bring the children to normal conditions in post emergency situations. So rehabilitation of education system in any post disaster response is the matter of great and first concern.(UNESCO, 2005).

\section{Material and Methods}

The present study was a survey. It is the most common form of research usually engaged by the educational researchers. The collected information from a large population about a particular topic provides deep insight in to the problem to resolve it purposefully. For data collection questionnaire was used. Population comprised all the Public educational institution of secondary level of KP and AJK, Emergency education programs initiated in 2005 in KPK and AJK and Secondary school teachers of public educational institution of KP and AJK. In the present study, sample of four districts from seven districts was taken randomly. Two hundred and sixteen teachers out of 2159 @ 10\% were drawn randomly (source ministry of education, 2007).Descriptive analyses were applied to obtain results and make suggestions. The collected data were put to data matrix on SPSS (version 16.0) and analyzed by using the Descriptive (Mean, SD). 


\section{Results and Discussion}

Table 1

Responses of Teachers in respect of Community Participation in Emergency Education Programs

\begin{tabular}{llcc}
\hline S. No & ITEMS & Yes\% & No\% \\
\hline 1 & Parents' teachers committees (PTCs) established in EE program. & 36 & 67 \\
2 & People of affected area participate in EE programs. & 55 & 45 \\
3 & Local community resources were used in EE program & 52 & 48 \\
4 & Education official visit EE programs & 52 & 48 \\
5 & $\begin{array}{l}\text { Parents participated in the school activities when needed. } \\
6\end{array}$ & 57 & 43 \\
& $\begin{array}{l}\text { Emergency Edu: program were monitored by the educati } \\
\text { authorities. }\end{array}$ & 58 & 42 \\
\hline
\end{tabular}

Mean $52 \quad 48$

According to Table1, 67\% teachers, the PTCs were not recognized in EE program. According to $57 \%$ teachers, parents attended the schools when called. Monitoring by officers of education was 58\% in EE programs. Overall responses of teachers were $52 \%$, regarding community participation in EE programs, was positive.

Table 2

Responses of Teachers in context of teaching and Learning in Emergency Education Programs

\begin{tabular}{llcc}
\hline S. No & \multicolumn{1}{c}{ ITEMS } & Yes\% & No\% \\
\hline 7 & Teachers were trained in to provide psychological support to students. & 42 & 58 \\
& Vocational training started in EE programs. & & \\
8 & Did you get any special teaching training to teach in such situation? & 38 & 62 \\
9 & There was proper evaluation method to check learning out comes & 62 & 38 \\
10 & There was adequate teaching and learning material. & 67 & 33 \\
11 & Learning material fulfilled the learning needs of students. & 60 & 40 \\
12 & Special modules for teaching in emergencies were provided & 48 & 52 \\
13 & & 39 & 61 \\
\hline & & $\mathbf{5 1}$ & $\mathbf{4 9}$ \\
\hline
\end{tabular}

Table 2 shows that $58 \%$ of the respondents were not provided any training in context of providing psychological support to students. More over $62 \%$ responses indicated the non availability of vocational training, sixty seven percent respondents were affirmative about adequate method of evaluation of students learning outcomes and $60 \%$ respondents confirm sufficient learning and teaching material, $61 \%$ teachers denied the provision of especial modules for teaching. Over all 51\%, responses regarding teaching and learning in emergency education programs, were positive. 
Table 3

Responses of Teachers in context of "Teachers and Education Personnel in Emergency Education Programs

\begin{tabular}{llcc}
\hline S. No & \multicolumn{1}{c}{ ITEMS } & Yes \% & No\% \\
\hline 14 & New staff was recruited for EE programs. & 68 & 32 \\
15 & Conditions for job were satisfactory. & 62 & 38 \\
16 & Supervision provided regular monitoring and support for personnel. & 51 & 49 \\
17 & Lifesaving skills were taught to students and teachers? & 36 & 64 \\
18 & You were briefed about job conditions and conduct code. & 54 & 46 \\
19 & The recruitment process of new teachers was a transparent. & 63 & 37 \\
\hline & & Mean & $\mathbf{5 6}$ \\
\hline
\end{tabular}

In Table 3, $68 \%$ responses confirm the recruitment of teachers in E.E programs. According to $62 \%$ responses were affirmative about good environment of job. Life saving skill was not taught to $64 \%$ teachers, and $63 \%$ responses were in favor of transparent recruitment. The $56 \%$ responses, regarding teachers and education personnel in emergency education programs, were positive.

\section{Table 4}

Responses of Teachers in context of Access and Learning Environment in Emergency Education Programs

\begin{tabular}{llcc}
\hline Item & \multicolumn{1}{c}{ ITEMS } & Yes\% & $\mathbf{N o} \%$ \\
\hline $\mathbf{2 0}$ & Induction policy for teachers was based on gender equality. & 89 & 11 \\
$\mathbf{2 1}$ & $\begin{array}{l}\text { There was discrimination for boys and girls from parents, to get } \\
\text { admission in the EE programs. }\end{array}$ & 57 & 43 \\
$\mathbf{2 2}$ & The school environment was safe and healthy for the students. & 67 & 33 \\
$\mathbf{2 3}$ & The school environment was good for the learning of students. & 42 & 58 \\
$\mathbf{2 4}$ & These schools help to bring the kids to normalcy. & 67 & 33 \\
$\mathbf{2 5}$ & The EE programs satisfy you in terms of learning out comes. & 34 & 66 \\
$\mathbf{2 6}$ & you think that children have enough education facilities. & 60 & 40 \\
\hline & Mean & $\mathbf{5 9}$ & $\mathbf{4 1}$ \\
\hline
\end{tabular}

In Table 4, 89\% teachers' induction was based on gender equality in emergency education programs. More over $67 \%$ responses confirmed the healthy and safe environment for kids. Similarly $58 \%$ responses were negative in context of good learning conditions. Over all 59 \% of responses regarding access and learning environment in emergency education programs, were positive.

Table 5

Responses of Teachers in context of Education Policy and Coordination in Emergency Education Programs

\begin{tabular}{llcc}
\hline Sr. No & \multicolumn{1}{c}{ Item } & \multicolumn{1}{c}{ Yes $\%$ No\% } \\
\hline $\mathbf{2 7}$ & Emergency education must be the part of teachers' education and & 84 & 16 \\
$\mathbf{2 8}$ & training. & 37 & 63 \\
& $\begin{array}{l}\text { There was suitable mechanism of sharing among all the stake } \\
\text { holders of EE. }\end{array}$ & 16 \\
&
\end{tabular}




\begin{tabular}{llcc}
\hline $\mathbf{2 9}$ & Education has role in minimizing the effects of disaster & 84 & 11 \\
$\mathbf{3 0}$ & We need proper mechanism of EE to respond in disasters in & 89 & \\
$\mathbf{3 1}$ & $\begin{array}{l}\text { future. } \\
\text { The government should introduce new flexible policy to promote }\end{array}$ & 76 & 24 \\
$\mathbf{3 2}$ & $\begin{array}{l}36 \\
\text { education in emergencies? }\end{array}$ & 64 \\
$\mathbf{3 3}$ & $\begin{array}{l}\text { Education was given priority in emergency response programs. } \\
\text { Emergency education should be the part of our curriculum. }\end{array}$ & $\mathbf{1 9}$ \\
\hline & $\mathbf{7 0}$ & $\mathbf{3 0}$ \\
\hline
\end{tabular}

In Table 5, 84\% responses confirmed the inclusion of EE in teachers' training programs Similarly $89 \%$ respondents were in favor of to make proper mechanism to respond in emergency situation and $81 \%$ were of the view to make EE the part of curriculum. Over all $70 \%$, responses in context of education policy and coordination in emergency education programs, were positive

\section{Conclusions}

The participation of community in EE programs was inadequate in terms of planning and implementation. Local human and material resources were not properly utilized. Te inducted faculty for schools was outside of the locality. The monitoring system of such schools was ordinary and as per usual routine.

Adequate material for teachers and students was given but it was in foreign standards. Teachers were not given modules or teachers guides and trainings how to teach those books. In spite that they had lack of training for such situations yet they provide comfort, stability to kids and taught them accordingly. In all EE programs, vocational trainings were not conducted. The schooling system was conventional and there was no special attention on assessment and evaluation of learning outcomes of students.

There was inadequate teaching staff in emergency education programs for the teaching of students. The staff recruited was untrained and in expert. They were paid very low remuneration. Their supervision requires much attention. The newly hired staff was not trained in life saving skills. Not great many teachers were aware of their job description and code of conduct.

Teachers in EE programs were hired on gender equality bases. The strength of girls in such schools was poor. The environment inside the institutions was safe for all. These EE programs successfully brought the kids out of the shock of disaster. The kids felt secure and were happy due to the fun activities there. Students were provided with playing and learning materials.

Emergency education programs faced lack of coordination. Poor mechanism of information sharing affected EE programs. There was no flexible policy introduced in such crisis situation to promote students in affected areas. Lack of coordination prevailed between education department and district administration. In most of the places conventional system of schooling was practiced. Most of the 
respondents were in favor of making emergency education as one of the integral part curriculum for teachers training programs.

\section{Discussion}

To know the present status of emergency education in Pakistan in the view of teachers was the primary motive of the study. The affected areas of Pakistan in the earthquake of 2005 were the population of the study. The collected data from the teachers in emergency education programs of these areas was tabulated through statistical techniques in SPSS. This earthquake was devastating and seriously it many districts of KP and Azad Jammu and Kashmir. Te magnitude of that disaster was too huge for Pakistan to cope up with it. There was much confusion and commotion. With the help of international agencies EE programs were started in AJK and KP. The districts of KP like Allai and Battagram had very low literacy rate. The findings of this study show that the people of such areas were kept away from all kinds of decision making, and were not allowed to have their voice indicating their needs. There was partial participation of community in the establishing tent schools. The teaching force recruited for tent schools and transitional schools was untrained and inexperienced.Therefore most of the children were left unaddressed. The learning materials were not locally supported therefore it was less interesting and less impressive for younger kids.

All the government departments were well engaged at national and provincial level but concerned education department was by passed in many cases. The study also revealed that emergency education has great role in lessening the bad effects of the disaster and it normalize the life of young people, so it should be the part of teacher training curriculum. Thus there should be a local force prepared for post emergency education programs. Similarly there should be such kind of local material which could be used in such conditions.

That is why all the International agencies including UN, Save the Children etc. were unable to respond in context of education in local environment of KP and AJK. Therefore children of these areas were passed through experimental projects which enhanced bitter confusion among the children and the situation became more complex.

\section{Recommendations}

Over all, the results of the study show positivity towards emergency education programs. There is variance in the responses which indicate the short comings and the reservations of the respondent teachers towards EE. Following recommendations suggest strategies to improve the emergency education in Pakistan

1. In any emergency education program there must be an active part of that locality. They must be given participation in Planning and its implementation. The learning material which is provided to students should be relevant 
linguistically. It should reflect the norms of that society. They must have a role in the monitoring of such educational projects.

2. The basics of emergency education should be made part of teacher curriculum and training. So that in case of emergency teachers should play their role positively.

3. Both formal and non formal education should be included in curricula of emergency education.

4. Assessment and evaluation system should be established to be utilized in such disastrous conditions in emergency education programs to check the learning outcomes of students.

5. There should be equal access for both the teacher and students in emergency education programs. 


\section{Reference}

Anderson, A. (2006). Standards put to the test: Implementing the INEE Minimum Standards for Education in Emergencies, Chronic Crisis and Early Reconstruction, Retrieved from Humanitarian Practice Network

Augilar, P.\& Rematal, G.(1998). Rapid educational response in emergencies: A discussion document, Paris: UNESCO, IIEP

Bisin, S. (2007). Transitional schools keep children learning in earthquake-affected areas of Pakistan, Retrieved from UNICEF website: www.unicef.org/education/Pakistan_39646.html

Dalrymple, Kelsey A. (2019). Mindful Learning: Early Childhood Care and Development for Refugee Children in Tanzania. Journal on Education in Emergencies 5 (1): 133-55. https://doi.org/10.33682/37cx-3017.

Fausto, Marincion, (2001). A cross- Cultural Analysis of Natural Disaster Response: The Northwest Italy Floods of 1994 compared to the U.S Midwest Floods of 1993.International journal of Mass Emergencies and Disasters. ISSN 0280-7270

Foucault, M. (1977). Discipline and punish, London, UK: Tavistock

Gay, L. R. (2000). Educational Research: Competencies for Analysis and Application, National Book Foundation, Islamabad

Hamdani, S., \& Shah, S. (2006). Disaster management of education: A lesson learnt from 8/10 earthquake, Proceedings of International Conference Earthquake 10/8 social, human \& gender issues. Islamabad: HEC

John, A. Cross (1983). A Half Century of Hazards Dissertation in Geography. International journal of Mass Emergencies and Disasters. ISSN 0280-7270 Website: www.http://ijmed.org/articles/175/

Novelli, Mario, Mieke T.A. Lopes Cardozo, and Alan Smith. 2017. The 4RS Framework:

Analyzing Education's Contribution to Sustainable Peacebuilding with Social Justice in Conflict Affected Contexts. Journal on Education in Emergencies 3(1): 14-43.

Pigozzi, J, M. (1999).Education in emergencies and for Reconstruction: A developmental approach, UNICEF Retrieved from www.unicef.org/girlseducation/files/EduEmerg.pdf Retrieved from Amazon website:www.amazon.com/reseach.. 
Save the Children. (2006). Re-write the future: Education for children in conflict-affected countries, Retrieved from http://www.campaignforeducation. org/ resources/sep2010.pdf

Sinclair,M. (2002). Planning education in and after emergencies. Paris: IIEP, UNESCO Publications

Sommers, M. (2004).Co-coordinating Education during Emergencies and reconstruction: Challenges and Responsibilities, International Institute for Educational Planning (IIEP)

UNESCO. (2005). Preliminary assessment of the impact of the earthquake on the education system of NWFP, Islamabad: UNESCO, Pakistan

UNICEF. (2005). Pakistan factsheets- emergency education, Retrieved from UNICEF website: from http://www.unicef.org/ pakistan/factsheets 994.htm

Willis, P. (1981). Learning to labor: How working-class kids get working class jobs,Columbia University Press; Morningside edition (April 15, 1981)

Yount, W. R. (2006). Research Design and Statistical Analysis for Christian Ministry,Retrieved on 15-07-2019 from website:https://www.worldcat.org / title/ research-design-and-statistical-analysis-for-christianministry/oclc/70080503 